\title{
Editorial
}

Jon Van Til*

\section{Introduction to the Symposium on Central and Eastern Europe}

DOI $10.1515 / \mathrm{npf}-2015-0024$

From the perspective of Euro-American geo-politics, the complex dance between public policy and nonprofit action has turned ugly in the three countries in which the three remarkable papers in this symposium are set. As the reverse third wave ${ }^{1}$ of authoritarian political domination sweeps through so much of the world, nowhere has it been stronger than in Hungary, Russia, and Ukraine.

In Russia and Hungary, Vladimir Putin and Viktor Orban have followed the long trail blazed by fellow autocrats ${ }^{2}$ to restrain and even neutralize critical voices emerging from the ranks of civil society. In particular, these organizations are branded as enemies of foreign powers and subjected to harassment, persecution, and even physical damage.

In Ukraine, on the other hand, the autocrat Yanukovich was removed from power in 2014 by a late form of "color revolution". When the smoke cleared, the elected autocrat had been replaced by a beleaguered congeries of political brokers and economic plutocrats who were greeted by a Russian invasion of their country's easternmost territories and the decisive loss of Crimea.

For students of the third sector, the lesson is clear. Inescapably, the nonprofit organization is a player in a nation's games of power, and, when an autocrat plays the power card, there is no neutral place in which to hide. Thus in Hungary, as Agnes Kover notes, nonprofits may be captured by both the state and its willing agents, such as favored churches. And in Russia, as Anna Leskinen observes, third sector organizations can remain "sparse and anemic" even in putative times of democratic expansion.

Ukraine tells us another story, as Svitlana Krasynska indicates in her paper. Its civil society maintained itself over the years before the 2014 Maidan revolution, asserted itself in mass protest at that time, and then found itself submerged

1 Cf. Huntington (1991) and Diamond (2015).

2 Consider here Mein Kampf or consult The Dictator's Handbook (http://dictatorshandbook.net/).

*Corresponding author: Jon Van Til, Budapest University of Jewish Studies, Budapest, Hungary 
by the overwhelming geopolitical forces that themselves captured the democratic momentum of the dramatic events in Kiev. ${ }^{3}$

The authors suggest that the situation is far more complex than it might first appear. They argue that we must understand unique civil society development in each of the countries they write about in order to fully appreciate what is currently happening. They provide their own (and they would argue much of their cultures') interpretations and the reader will benefit from a careful reading of their analyses. But first, I will discuss three themes that emerge from my own efforts to compare and contrast the three articles:

(1) How and why did the sector remain an independent force in Ukraine while it came under the so much more direct governmental control shown in the Russian and Hungarian cases?

(2) What clues do the cases offer as to the conditions that loosen and invite, or alternatively, restrain, mass oppositional movement to authoritarian regimes?

(3) To what extent do the three cases indicate the overwhelming potency of geopolitical factors as constraints on the relations between government and the third sector?

\section{Ukrainian Exceptionalism?}

In her paper, Krasynska describes a third sector struggling to survive in a turbulent political and economic context. Her interviews with five nonprofit executives tell a story of determined efforts to advance organizational missions in the face of an unsupportive political environment. The acquisition of foreign sources of financial support, achieved by four of these organizations, allowed for a distance to be maintained between nonprofits and the state. As one executive told Krasynska: "I do not think I can help you very much, as I know nothing about the laws, and politics do not affect us. We are being funded completely by [the European Commission]."

The Hungarian organizations described by Kover are also mission-centered, and focus their attention on achieving their service goals in a changing funding environment. When the Fidesz party was elected to parliamentary dominance in 2010, nonprofit leaders experienced a revolution in their relationship with

3 Groups among the Maidan protesters were apparently assisted by not always covert support from the U.S. State Department (Cohen 2014). And in Hungary, as told by a recent U.S. ambassador, very high priority in the Embassy was often given to that country's provision of military assistance in Afghanistan (Kounalakis, 2015). 
governmental funders. In particular, as new decisionmakers assumed power, these leaders were pushed aside in favor of other supplicant nonprofit leaders and funding was lost. Resource dependence remained the key factor of concern, but resources were nowhere to be found. The new regime assumed full control of domestic spending, and tightened its grip on funding from outside the country's boundary. The nonprofit sector was dramatically reshaped as government recast itself as its master rather than its facilitator.

In Russia, Leskinen focuses on patterns of state-sector relations that embody both legacy and change. Essentially a critique of Howard's influential 2003 article, her contribution notes that national experiences and characteristic vary within the Central and East European region. She also asserts that "Focusing on informal as well as formal civil society organizations ... is essential for understanding the cultural aspects of civic activity in Russia and its dynamics over time, as well as the interaction of the formal and informal dimensions of civic life."

Taken together, the three articles depict a third sector in each country focused on their tasks at hand, assiduously seeking the social and financial support required to achieve their service goals. In each of the three countries, the sector proposes activity and, to large extent, the state disposes. If foreign philanthropic support is deemed acceptable, or even welcome, the nonprofit may look there for support. Thus, in Ukraine support from external sources was welcomed, and so was sought and achieved. In Russia and Hungary, however, the increasingly centralized Putin and Orban regimes began to look askance at such patterns of funding, identifying them as interventions by unfriendly or even enemy countries.

And, of course, in Ukraine came the Maidan revolution, where Leskinen's third sector of individual and non-formal organizational forces and Krasynska's shadow third sector took to the square and dislodged the corrupt tyrant. Meanwhile, opposition forces in Hungary restrained their mass expressions to peaceful and intermittent protest (Krasztev and Van Til, forthcoming 2015); in Russia such demonstrations came under increased official observation. He who must be obeyed remains in firm control of Russia and Hungary.

\section{The Varying Force of Society's Third Sector}

Civil society is weak in the three countries under our consideration. But it is also capable of forcing revolutions, as has been shown twice in Ukraine over the past dozen years. And the threat of similar mass uprisings surely conditions the stern watch the rulers of Russia and Hungary maintain over nonprofits in their counties.

How is it possible that a social force that seems so weak and malleable can, within weeks, bring a country's functioning to a halt and force a seemingly 
untouchable autocratic ruler to flee his position? The answer to this puzzling question may be found in the logic of our three authors.

Certainly it will be necessary to start with a conception of what is meant by "civil society." As Leskinen observes, we must include both the informal and the formal organizations of society - personal networks as well as chartered associations. And, as Kover notes, we must also disabuse ourselves of the notion that nonprofit activists always stand firmly with progressive forces toward the left side of a country's political ideology.

Krasynska advances our search for an answer to the question with her concept of the "shadow third sector." It was not formal nonprofit organizations that led their members' troops to Kiev's Maidan; it was a looser collection of networked activists. The contemporary revolution is neither mass nor pluralist, to use Kornhauser's (1959) classic theory: its leading force is a hybrid organization, developed quickly for its purposes. It uses the Internet to recruit its members and draws on a wide range of pre-existing personal and organizational networks.

This is the force that draws hundreds of thousands of Hungarians to participate in "days of outrage" to protest policies of Internet taxation or new highway levies. It is a social form representing a new social paradigm ${ }^{4}$ that rests on a combination of the oldest form of communication, word of mouth, with the newest, a call on Facebook. It is this force that Orban seeks to control by giving permission to organize, but careful observing, and yes, regulating, by the employment of legions of well-trained riot police. Putin's means of control, it would appear, are often somewhat more direct.

In any case, what the regime fears is what happens when a seemingly ephemeral demonstration transforms itself into a determined occupation of symbolic space - when the demonstrators sit down in the main square and become joined by an increasing stream of networked activists and new recruits. When that occurs, a relatively docile social force assumes a fearsome revolutionary cast. The third sector becomes the first force within its land. ${ }^{5}$

\section{The Geopolitical Context of It All}

The three countries studied by our colleagues in this symposium are closely linked by a set of geopolitical concerns. They are neighbors; they sell each other resources that they need; they hold claims on populations and areas within each

4 Cf. McCully (2014) and Sulek and Van Til (2015).

5 Cf. Young (1988). 
other's boundaries. When these three countries relate among themselves, politically or economically, they do so within the contexts of a series of complex relations. ${ }^{6}$ They deal with issues that have long troubled their region and are no easier to resolve than they were some 72 years ago, when Arthur Koestler's (1943) fictional Bernard, ${ }^{7}$ a visionary committed to the conquest of Europe, observed:

\footnotetext{
Close your eyes. Imagine Europe up to the Urals as an empty space on the map. There are only fields of energy...Connect those sources... with lines and you get the distributive network. Draw circles of varying radius around the points of intervention and you get the centres of industrial agglomeration; work out the human labour required to feed the net at any given point and you get the adequate density of population for any district...
}

Unlike Bernard, the rulers of Hungary and Ukraine do not seek external conquest, though the same cannot be said of Russia's Putin. Both he and a set of decisionmakers in the U.S. government seem to be doing their best to structure a twentyfirst-century cold war re-run. Hungary gets into this act with the warmth Orban expressed toward Putin, and the State Department, acting both in Hungary and Ukraine, has not pulled its punches when the topic of Russia arises.

Thus these three nations, by being enmeshed in their various needs for energy and wants for territory and control over their ethnic brothers and cousins, find little room for philanthropic and associational innovation. Accordingly, short shrift is given to many of the more uplifting ideas within third sector thinking - such as deliberative democracy, citizen participation, income redistribution, social diversity, and human rights. Russia, Hungary, and Ukraine, it would seem, are in the active process of hollowing out the remaining democratic and pluralist institutions within their societies as they desperately struggle with the challenges of contemporary geopolitics.

\section{Conclusion: A Third Sector Is Needed in These Lands}

In the Western world, the vision of the third sector and what it can contribute is often vibrant and optimistic. Its components - active philanthropic giving of money and time, sociable gathering and association, and effective organizational assertion - are closely examined, generally welcomed, and frequently celebrated.

6 Cf. Mungiu-Pippidi (2015).

7 Arrival and Departure, 142-3. 
The idea of philanthropy partners well with the vision of a civil society - a way of living and working together and resolving differences that may arise by means of dialogue and deliberation. And a civil society achieves its greatest effect when it is implemented through structures of a truly independent third sector, whose organizations take, and are provided, space to experiment in the range of the solutions they devise for actions that address, ameliorate, and (hopefully) even resolve pressing social problems and issues.

In the three countries under review, the third sector may be seen as insufficiently appreciated, supported, or effectively maintained. Their governments insist on going it alone, turning to their friends in corporate offices for support in their often desperate efforts to secure domestic tranquility. The failure of these countries to construct a viable and productive third sector will surely continue to be a source of national distress in the years ahead. And the following three papers mark well the challenges that lie ahead

\section{Reference}

Cohen, S. F. 2014. "Patriotic Heresy vs. the New Cold War." Nation 299 (11):22-6.

Diamond, L. 2015. “Is Democracy in Decline?.” Journal of Democracy 26 (1):141-55.

Huntington, S. P. 1991. “Democracy's Third Wave.” Journal of Democracy 2 (2):12-34.

Koestler, A. 1943. Arrival and Departure. New York: Macmillan.

Kornhauser, W. 1959. The Politics of Mass Society. Glencoe, IL: Free Press.

Kounalakis, E. 2015. Madam Ambassador. New York: The New Press.

Krasztev, P., and J. Van Til 2015, forthcoming. The Hungarian Patient. Budapest: Central European University Press.

McCully, G. 2014. Philanthropy's Current Paradigm-Shift. Watertown, MA: Massachusetts Catalogue of Philanthropy.

Mungiu-Pippidi, A. 2015. “The Splintering of Postcommunist Europe." Journal of Democracy 26 (1):88-100.

Sulek, M., and J. Van Til 2015. "Philanthropy, Civil Society, and Prospects for a Truly Independent Third Sector in the CEE Region." Proposal submitted to the European Research Council.

Young, D. R. 1988. The Nonprofit Sector as the First Sector: Policy Implications. Washington, DC: Independent Sector. 